
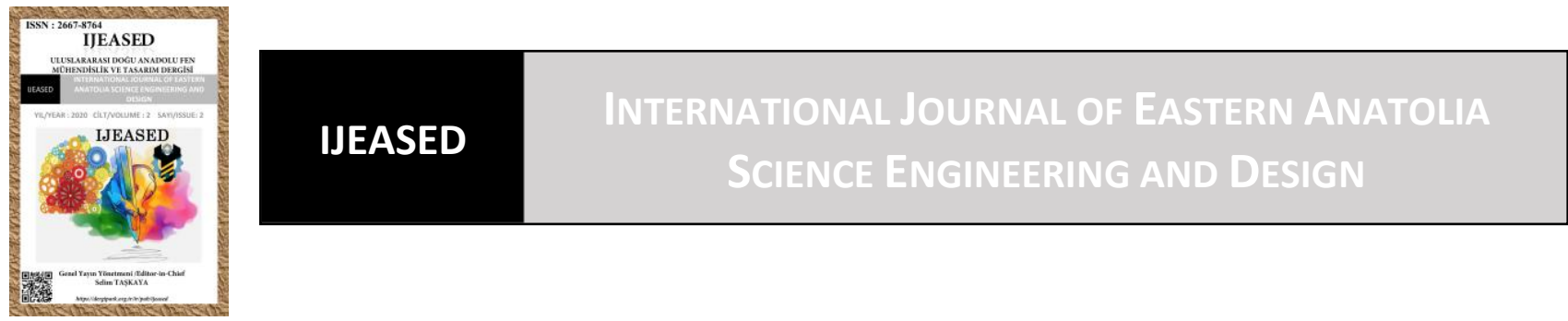

\author{
Uluslararası Doğu Anadolu Fen Mühendislik ve Tasarım Dergisi \\ ISSN: 2667-8764, 2(2), 434-445, 2020 \\ https://dergipark.org.tr/tr/pub/ijeased
}

Araştırma Makalesi / Research Article

Doi: $10.47898 /$ ijeased.813709

\title{
Mekansal Aidiyet ve Kültür Turizmi İlişkisi
}

\author{
Sebile Merve ÖZTÜRK ${ }^{1 *}$, Hicran Hanım HALAÇ ${ }^{2}$
}

${ }^{1}$ Karabük Üniversitesi, Mimarlık Fakültesi, Karabük,78000, Türkiye.

${ }^{2}$ Eskişehir Teknik Üniversitesi, Mimarlık ve Tasarım Fakültesi, Eskişehir, 26000, Türkiye.

\begin{tabular}{|c|c|c|}
\hline Yazar Kimliği / Author ID (ORCID Number) & \multicolumn{2}{|c|}{ Makale Süreci / Article Process } \\
\hline Sorumlu Yazar / Corresponding author: & Geliş Tarihi / Received Date : & 21.10 .2020 \\
\hline smozturk@karabuk.edu.tr & Revizyon Tarihi / Revision Date : & 05.11 .2020 \\
\hline //orcid.org/ 0000-0002-2790-067X, S & Kabul Tarihi / Accepted Date : & 05.12 .2020 \\
\hline (iD) https://orcid.org/ 0000-0001-8046-9914 , H.H. Halaç & Yayım Tarihi / Published Date & 15.12 .2020 \\
\hline
\end{tabular}

Alıntı / Cite : Öztürk, S.M., Halaç, H.H. (2020). Mekansal Aidiyet ve Kültür Turizmi İlişkisi, Uluslararası Doğu Anadolu Fen Mühendislik ve Tasarım Dergisi, 2(2), 434-445.

\section{Özet}

Aidiyet, bireylerin çeşitli aktiviteler, fiziksel etmenler ve deneyim kazandıkları mekanlar ile aralarında kurdukları karşılıklı etkileşimler şeklinde tanımlanmaktadır. Mekânsal aidiyet ise kısaca belirli bir çevreye karşı gelişen duygusal bağ olarak açıklanabilir. Tarihi çevrede gerçekleştirilen çalışmalarda mekânsal aidiyet konusu, koruma sürecinin sürdürülebilirliğini etkileyen başlıklar altında incelenmiştir. Koruma anlayışında yapılı çevrenin yanında bölgenin, geleneksel yaşamı ve sosyal-kültürel değerleriyle birlikte devamlılığının sağlanması yaklaşımı bulunmaktadır. Bu yaklaşımın gerçekleştirilmesinde alternatif bir turizm türü olan kültür turizminin fayda sağlayacağı düşünülmektedir. Mekânsal aidiyet turizm faaliyetlerinde farklı açılardan değerlendirilmiştir. Ziyaret ettikleri bölgeden memnun ayrılan turistlerin yere bağlılık duygusu geliştirdikleri ve yeniden ziyaret etme olasılıklarının arttığı ortaya konulmuştur. Tarihi bir yerleşim olan Yörük köyü, dışa göç problemi yaşaması ve sahip olduğu köklü değerlerin devamlılığının tehlike altına girmiş olması nedeniyle çalışma alanı olarak seçilmiştir. Kültür turizmi, bölgedeki geleneksel geçim yollarının yerini almış ve koruma sürecine olumlu etki edecek bir potansiyeli barındırmaktadır. Çalışmanın amacı, turizmin bölgede daha etkin biçimde kullanmasına yardımcı olmanın bir yolu olarak, mekânsal aidiyetin potansiyel faydasını araştırmak ve konunun, koruma faaliyetlerinde de kullanımı için önerilerde bulunmaktır. Buradan hareketle çalışmada, ziyaretçilerin bölgeye karşı hissettiği duygusal ve işlevsel bağların araştırılması üzerinde durulmuştur. Çalışmanın, mevcut koruma anlayışının sınırlılıklarına dair farkındalık ve köyde gerçekleştirilecek turizm ile ilgili çalışmalar için bir altlık oluşturacağı düşünülmektedir.

Anahtar Kelimeler: Aidiyet, Mekânsal Aidiyet, Yörük Köyü, Tarihi Çevre, Kültür Turizmi. 


\title{
Spatial Belonging and Cultural Tourism Relationship
}

\begin{abstract}
Belonging is defined as the mutual interactions between individuals and various activities, physical factors and places where they gain experience. Spatial belonging can be explained briefly as an emotional bond that develops against a specific environment. In the studies carried out in the historical environment, the subject of spatial belonging has been examined under the headings that affect the sustainability of the conservation process. In the conservation approach, besides the built environment, there is an approach to ensure the continuity of the region with its traditional life and social-cultural values. It is thought that cultural tourism, which is an alternative tourism type, will be beneficial in realizing this approach. Spatial belonging has been evaluated from different aspects in tourism activities. It has been demonstrated that tourists who leave satisfied with the region they visit develop a sense of attachment to the place and are more likely to revisit. Yörük village, which is a historical settlement, has been chosen as a study area due to the problem of emigration and the continuity of its deep-rooted values. Cultural tourism has replaced traditional livelihoods in the region and has the potential to positively affect the conservation process. The aim of the study is to explore the potential benefit of spatial belonging as a way of helping tourism to use it more effectively in the region and to make suggestions for the use of the issue in conservation activities. Based on this, the study focused on the investigation of the emotional and functional ties that visitors feel towards the region. It is thought that the study will raise awareness about the limitations of the current conservation approach and form a basis for tourism-related studies to be carried out in the village.
\end{abstract}

Keywords: Sense of Belonging, Spatial Belonging, Yörük Village, Historical Environment, Cultural Tourism.

\section{Giriş}

Aidiyet kavramı son yirmi yılda, çevre psikolojisi ve yönetimi başta olmak üzere coğrafya ve mimarlık gibi farklı alanlarda gerçekleştirilen çalışmalara konu olmuştur. Bu kavram kültürel miras alanlarında ise koruma sürecini sosyal ve kültürel açıdan desteklemek amacıyla çoğunlukla kimlik ve göç kavramları özelinde çalışılmaktadır. Tarihi alanlarda gerçekleştirilen birçok çalışmada, bu alanlardaki plansız ve hızlı işlev değişikliklerinin sonuçları üzerine durulmuştur. Bu durumun aynı zamanda hızlı kullanıcı değişikliğine neden olarak kullanıcıların mekânsal aidiyet duygularının azalmasına yol açtığı ortaya konulmuştur. Tarihi alanlarda yaşanan bu problemler, korumanın önündeki engellerden biri olmanın yanı sıra kentlerin değerlerinin, mekan ve zamanda algılanabilirliklerinin de kaybolmasına neden olmaktadır (Şentürk ve Gülersoy, 2019). Kullanıcının yaşadığı mekana duyduğu aidiyet duygusunun güçlendirilmesi yoluyla, mekanın sosyal ve kültürel sürekliliğine katkıda bulunulacağı düşünülmektedir. $\mathrm{Bu}$ amaçla daha önce köydeki yerel halkın mekânsal aidiyeti üzerine bir çalışma gerçekleştirilmiştir. Çalışmada, köye güçlü bir aidiyet hisseden halkın, köyde ikamet etme tercihini etkileyen en önemli kriterin, geçim kaynağı olarak gördükleri turizm potansiyelinin değerlendirilmesi düşüncesi olduğu anlaş1lmıştır (Öztürk, 2020). $\mathrm{Bu}$ çalışmayla birlikte, kültür turizminin bölgede daha verimli kullanılması gerekliliği düşüncesi ortaya çıkmıştır. Kültür turizmi, sürdürülebilirlik kriterleri ve planlamalarıyla geliştirilerek kültürel 
mirasın korunmasında bir araç haline gelebilir ve yerel değerlerin küreselleşme karşısında yok olmasının önüne geçilebilir (Meydan Uygur ve Baykan, 2008). Kültür turizminin sözü edilen bağlamda değerlendirilebilmesi, ziyaretlerinden memnun olan ve bu memnuniyet sonucunda bölgeye karşı aidiyet duygusu gelişen turistler ile mümkündür. Buradan hareketle süreli kullanıcı grubunu tanımlayan turistler üzerinde, bölge hakkındaki memnuniyet durumlarının ve geçirilen süre içerisinde ortaya çıkan aidiyet duygularının ölçülmesini hedefleyen bir çalışma yapmanın gerekli olduğu düşünülmüştür. Çalışmanın amacı, bireylerin kısa süreli ziyaret ettikleri bölgede turizmin daha etkin biçimde kullanmasına yardımcı olmanın bir yolu olarak, mekânsal aidiyetin potansiyel faydasını araştırmak ve konunun, koruma faaliyetlerinde de kullanımı için önerilerde bulunmaktır.

\section{Mekânsal Aidiyet}

Mekânsal aidiyet kavramı; duyguların, bilgilerin, inançların ve davranışların karşılıklı etkileşimini içermektedir. $\mathrm{Bu}$ nedenle belirli bir çevreye karşı gelişen duygusal bağ (Low ve Altman, 1992; Hidalgo ve Hernández, 2001) veya bireysel değerlerin ve belirli bir çevresel ortamla özdeşleşmenin derecesi olarak tanımlamaktadır (Moore ve Scott, 2003). Bu kavramsallaştırma insanlar ve mekanlar arasındaki etkileşimi vurgular. Ortamla olan etkileşim aracılığıyla fiziksel alan aidiyet duygusunun nesnesi haline gelir. Mekânsal aidiyet, genellikle bireylerin mekanı tanıması ve ona değer vermeye başlamasıyla birlikte ortaya çıkar (Kyle ve ark., 2005).

Mekânsal aidiyet çalışmalarda, yere bağlılık (işlevsel aidiyet) ve yer kimliği (duygusal aidiyet) olarak iki boyutta araştırılmıştır. Yere bağlılık belirli hedefleri veya istenilen etkinlikleri destekleyen koşullar sağlamak adına yerin sahip olduğu önemi yansıtır. $\mathrm{Bu}$ işlevsel bağlantı, bölgenin fiziksel özelliklerine göre şekillenir ve sık ziyarete imkan verecek yakınlıkta olduğunda güçlenebilir. Yere bağlılık için belirli bir ortamda devam eden bir etkileşimin olması gereklidir (Bricker ve Kerstetter 2000; Williams ve Vaske, 2003). Yer kimliği ise, yaşama anlam ve amaç veren duygu ve ilişkiler için bir yerin sembolik önemini ifade eder. Yer kimliği, kişinin topluluğuna ait olma duygularını artırır ve öz kimliğinin bir bileşeni olarak tanımlanır. Bazı araştırmacılar, yere bağl1lık nedeniyle tekrarlanan bir ziyaret geçmişinin yer kimliğine yol açabileceğini öne sürmüştür (Williams ve Vaske, 2003). Özetle birçok etkileşimin gerçekleştiği yerler, belirli bir etkinliği üstlenmek için iyi bir yer olduğundan birey tarafından değerli bulunabildiği gibi, duygusalsembolik nedenlerle veya her ikisi için de ayrı ayrı olarak değerli bulunabilir (Kyle ve ark., 2005). 
Aidiyet duygusu araştırmalarda, çevre psikolojisi literatüründe sosyal bağlılık boyutu üzerinden de incelemeye alınmıştır. Konuyla ilgili olarak Hidalgo ve Hernández (2001) çalışmalarında sosyal bağların, yapılı çevre ile olan bağlılıktan daha güçlü olduğunu ortaya koymuştur.

Son y1llarda mekânsal aidiyet ve onun yerin değerini anlamaya yönelik ekonomik olmayan yaklaşımı, doğal ve yapılı çevrenin yönetimi alanında da kabul görmektedir. Yöneticiler ve planlamacılar, kaynak çatışmalarını anlamak ve kilit paydaşları belirlemek için bir araç olarak mekânsal aidiyet kavramını kullanmaktadır. Bu alandaki çalışmalarda, halkın katılım sürecine dahil edilecek aidiyet duygusu güçlü bireylerin, kullanıcı grupları için yer kalitesinin güvenilir göstergeleri haline gelebileceği düşünülmektedir (Warzecha ve Lime, 2001).

\section{Mekânsal Aidiyet ve Kültür Turizmi İlişkisi}

Mekânsal aidiyet konusu tarihi çevrelerde, koruma sürecinin sürdürülebilirliğini etkileyen başlıklar altında incelenmiştir. Küreselleşme kaynaklı değişen kimlik yapılarının aidiyete etkisi, mekanlarda kullanıcı sürekliliği ve aidiyet ilişkisi, göçün etkisi ile mekânsal değişime uğrayan bölgelerde kullanıcı aidiyeti çalışılan konu başlıkları arasındadır (Altınörs Çırak, 2019; Şentürk ve Gülersoy; 2019, Geçkili, 2018). Koruma anlayışında yapılı çevrenin yanında, bölgenin sahip olduğu geleneksel yaşam ve yerel değerlerle birlikte sürdürülebilirliğinin sağlanması fikri üzerinde durulmaktadır. $\mathrm{Bu}$ anlamda ülkeler için alternatif bir turizm türü olan kültür turizminin, gelir sağlayıcı etkisi yanı sıra kültürel değerlerin korunmasında da fayda sağlayacağı düşünülmektedir. Kültür turizmi içinde turistler hem farklı deneyimler kazanmak hem de arkeolojik alanları, müzeleri, mimari eserleri, sanat galerilerini görmek ve festivallere, sanat etkinlilerine, dini festivallere katılmak amacını taşımaktadır (Meydan Uygur ve Baykan, 2008). Mekânsal aidiyet, turizm pazarlamasında önemli bir rol oynamaktadır. Çünkü ziyaret ettikleri bölgede memnuniyet düzeyleri yüksek olan turistlerde yere bağlılık duygusu gelişir ve yeniden ziyaret etme olasılıkları artar (George ve George, 2004). Bunun yanında turistlerin bir yer ile olan olumlu duygusal ve bilişsel bağları, bir ortam hakkındaki eleştirel değerlendirmesini etkileyebilmektedir (Yüksel ve ark., 2010). Mekânsal aidiyetin bölgenin görsel estetiği, çekiciliği, turistlerin kişisel katılımı ve memnuniyetlerinden etkilendiği ileri sürülmektedir (Vada ve ark., 2019). 


\section{Yörük Köyü}

Tarihi bir bölge olan Yörük köyünde gerçekleştirilmiş olan bu çalışmada, mekânsal aidiyetin kültür turizmi ile ilişsisi üzerinde durulmaktadır. Safranbolu ilçesinin küçük bir modelini temsil eden Yörük köyü, 1997 yılında Kültür ve Turizm Bakanlığı tarafından bir Türkmen köyü olması nedeniyle kentsel sit alanı ilan edilerek korumaya alınmıştır. Tarihi 14. ve 15. yüzyıllarda konargöçer bir Yörük Obasına dayanan köydeki somut ve kültürel değerler sadece Yörük yaşamından izleri değil, kentsel bir kültürün de özelliklerini taşıması sebebiyle turistler için önemli bir ziyaret noktasıdır. Köyün sahip olduğu kentli yaşam kültürünün kazanılmasında, 16 yüzyılda askeri amaçlı başlayan, 19. yüzyılda ise eğitim, iş ve ticaret amacıyla devam eden dışa göç hareketinin etkili olduğu bilinmektedir (Türker ve ark., 2011). Bu süreçte ekonomik olarak refah düzeyi yükselen sakinlerin elde ettikleri deneyim, konut tasarımlarında ve günlük yaşam tarzında kendini gösterirken, inançları üzerinde bir değişime neden olmamıştır (Türker ve ark., 2011).

Geleneksel yaşamı koruma çabası içerisinde olan köyde her yıl düzenli olarak köy ağası seçiminin yapıldığg etkinlikler düzenlenmektedir. Ancak günümüzde hızla değişen yaşam biçimleri köyün giyim, eğlence ve yemek kültürünü olumsuz etkilemiştir. Konargöçer yaşam tarzını yansıtan Yörük kültürünün karakteristik özellikleri kaybolmaya yüz tutmuştur. Yaşamın devam etmediği tarihi konaklarda bakımsız nedeniyle ciddi hasarlar oluşmuştur (Şekil 1). Bunun yanında dışa göç problemi yaşayan köyde tarım ve hayvancılık olan geçim kaynağının yerini kültür turizmi almıştır (Göçer, 2018). Göçün önlenebilmesi için turizmden beklenen, sağlayacağı yeni iş olanaklarıyla birlikte mekandaki kullanıcı sürekliliğinin sağlanmasıdır. Bu anlamda bölgenin kültür turizmini daha verimli kullanabilmek için bir potansiyelinin olup olmadığının belirlenmesinde, mekanın süreli kullanıcıları olan turistlerin bölgeye karşı geliştirdikleri aidiyet duygusunun ve memnuniyet düzeyinin ölçülmesi önemli görülmektedir.
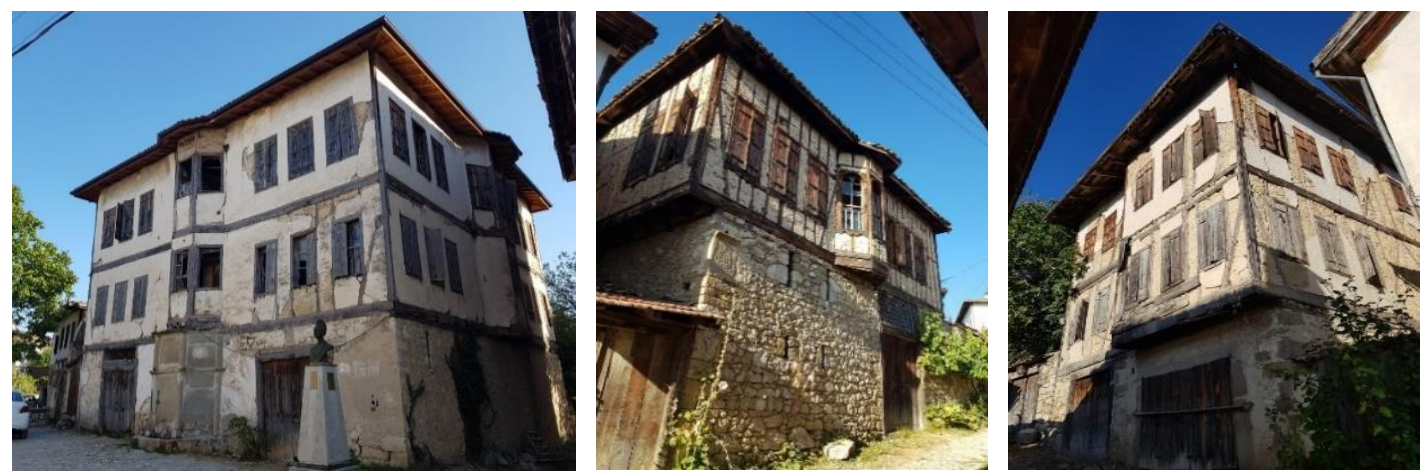

Şekil 1. Yaşamın devam etmediği konak örnekleri. 


\section{Materyal ve Metot}

Bir çevrede gerçekleştirilen deneyim hem fiziksel hem de sosyal içerikli olabilir. Mekânsal aidiyet literatürü incelendiğinde, fiziksel çevreye karşı gelişen ve sosyal ilişkilere dayanan iki tür bağlanma şeklinin araştırılma konusu olduğu görülmektedir (Vada ve ark., 2019). Gerçekleştirilen ilk çalışmalar mekânsal aidiyetin yere bağlılık ve yer kimliği olmak üzere iki bileşenli bir yap1 üzerinden incelenmiş (Williams ve Roggenbuck, 1989) ve daha sonra bu yapıya sosyal ve duygusal boyut eklenmiştir (Kyle ve ark., 2005). Araştırmacılar, bireyin bir alana yönelik geliştireceği aidiyet düzeyinin en çok hangi değişkenlerden etkilendiğini anlamaya çalışmışlardır. Çalışma konuları arasında mekânsal aidiyet ve motivasyonlar, katılım, hedef çekicilik, yönetimsel açıdan önemli olabilecek diğer değişkenlerin incelenmesi, yeniden ziyaret niyetleri ve çevre yanlısı davranışların gelişimi arasındaki ilişkiler yer almıştır. Son dönemde ise araştırmacılar, mekânsal aidiyeti turizm araştırmalarına dahil etmeye başlamıştır. Bu alanda gerçekleştirilen çalışmalarda, rekreasyon ve konaklama bağlamında mekânsal aidiyet ve memnuniyet arasındaki ilişki araştırılmıştır (Yüksel ve ark., 2010).

Mekânsal aidiyet bu çalışmada, bir yere karşı hissedilen duygusal ve işlevsel bir bağ olarak ele alınmıştır. Veri toplama aracı olarak anket kullanılmıştır. Bölgeyi ziyarete gelen süreli kullanıcı grubundan seçilen 30 kişiye anket uygulanmış ve elde edilen verilerin frekans dağılımları tablolar halinde sunulmuştur. Çalışmada kullanılan anketin oluşturulmasında mekânsal aidiyet kavramı üzerine yapılan araştırmalar incelenerek, William ve Vaske (2003)'ün rekreasyonel bağlamda, mekânsal aidiyet boyutlarının hem psikolojik hem de davranışsal değişkenler arasındaki ilişkisinin analizini yaptıkları çalışması referans alınmıştır.

Yörük köyü, Safranbolu ve Amasra gibi birbirine yakın tarihi ve turistik gezi noktalarını içeren bir bölgede bulunmaktadır. Planlanan geziler diğer tarihi kentleri de içeren bir rota dahilinde yaz aylarında genellikle dini ve milli bayramlarda yoğunlaşmaktadır (Ceylan ve Somuncu, 2016). $\mathrm{Bu}$ nedenle anket çalışması, milli bayramı da içeren 3 günlük tatil sürecinde ziyaretin en yoğun olduğu 12.00-17.00 saatleri arasında uygulanmıştır. Çalışmada, süreli kullanıcılara Yörük köyünü ziyaretleri sonrasında, demografik bilgileri içeren soruların ardından, bölgeyi ziyaret nedenleri ve alanda bulunma sürelini içeren 6 soru sorulmuştur. Daha sonra alana karşı duydukları aidiyetin ölçülmesi amacıyla hazırlanmış olan 3'lü likert ölçekli 9 soruya cevap vermeleri beklenmiştir. 


\section{Bulgular ve Tartışma}

Anket çalışması analizine öncelikle demografik özellikler belirlenerek başlanmış daha sonra mekan aidiyeti ile ilgili soru grubuna geçilmiştir. Katılımcıların \%30’unu erkekler \%70'ini ise kadınlar oluşturmaktadır. Yaş dağılımlarına bakıldığında ağırlıklı olarak 18-24 (\%30) ve 25-35 $(\% 23,33)$ genç yaş aralıklarının bölgeyi ziyaret ettikleri görülmektedir. 65 yaş üstü ziyaretçi dışında her yaş grubundan ziyaretçi ile iletişime geçilmiştir. Ek olarak kadınlarda 55-65 yaş aralığındaki oran da dikkat çekicidir (Tablo 1).

Tablo 1. Kadın ve erkek katılımcıların yaş dağılımları.

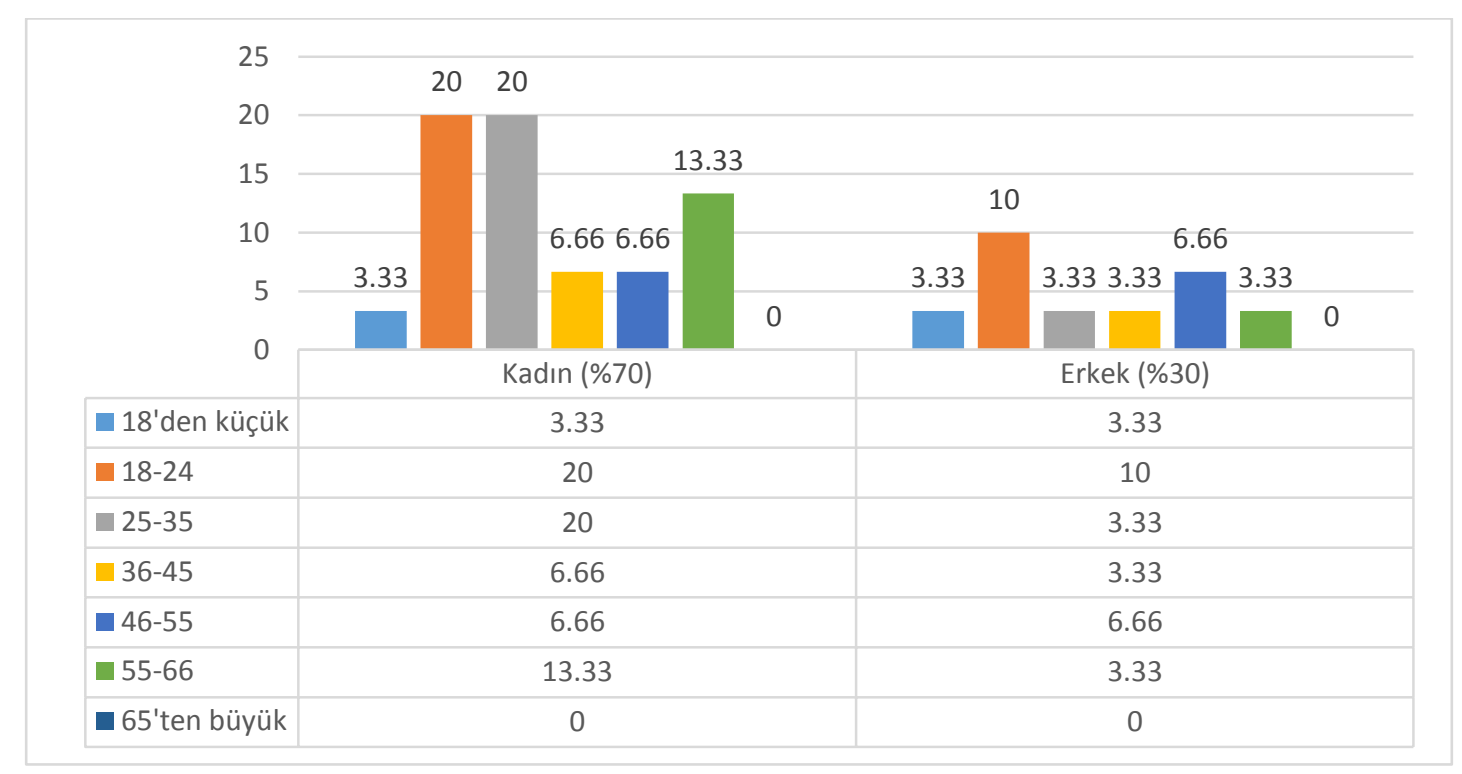

Mekânsal aidiyet ve mekanda geçirilen süre arasındaki olumlu ilişki düşünülerek (Williams ve Vaske, 2003), katılımcılara mekanda bulunma süreleri sorulmuştur. Cevaplar incelendiğinde; 2 kişinin (\%6,66) 5-15 gün arası, kalan 28 kişinin ise $(\% 93,34) 5$ günden daha az süredir bölgede bulunduğu belirlenmiştir. Bunun yanında 5 günden daha az süredir bölgede bulunan katılımcılar "eğer imkanım olsa burada daha fazla kalmak isterdim" ifadesine \%50 oranında "orta düzeyde" ve \%21,42 oranında ise "tam olarak" katılmışlardır (Tablo 2). Bu durumunun nedenin Yörük köyünde konaklamanın tarihi konaklarda gerçekleştirilmesi ve bu konakların sayısının talep azlığı ve dışa göç sebebiyle giderek azalması olduğu düşünülmektedir. Ayrıca köyde gerçekleştirecek farklı aktivitelerin bulunmaması da mekanda bulunma süresi üzerinde etkili olabilir. "Buradaki olanaklar birçok yerde var" ifadesine \%36,66 oranında "orta düzeyde" ve yine \%36,66 oranında "tam olarak" 
katılımın olması bahsedilen durumu destekler niteliktedir. Köyde gerçekleştirilebilecekler arasında; müze konakların gezilmesi, yerel halkın kendi üretimi olan konakların önlerinde satışa sundukları ürünlerin alışverişi ve yöresel yemekler sunan bir işletmede yemek yeme bulunmaktadır (Tablo 3).

Tablo 2. Ziyaretçilerin "Eğer imkanım olsa burada daha fazla kalmak isterdim" ifadesine katılım oranları.

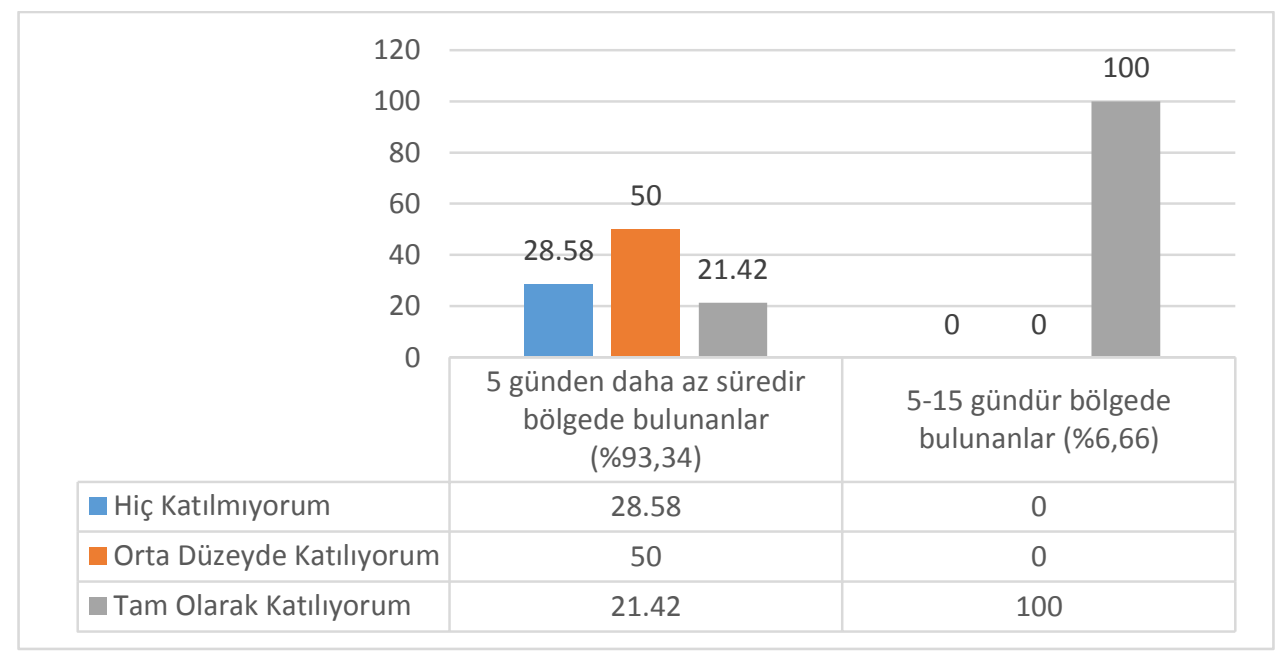

Tablo 3. Ziyaretçilerin "Buradaki olanaklar birçok yerde var" ifadesine katılma oranları.

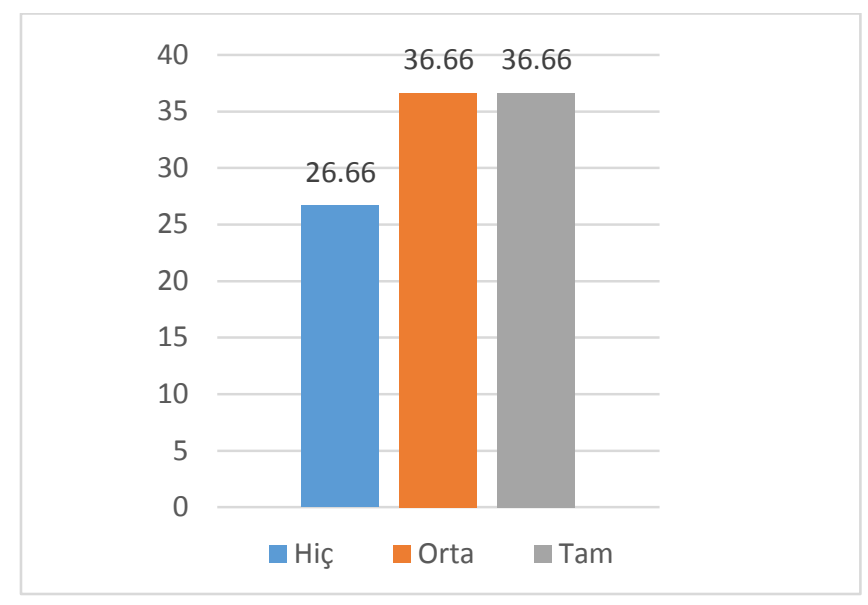

Mekânsal aidiyeti dolaylı olarak ölçmeyi amaçlayan "bölge ile aramda bir bağ oluştuğunu hissediyorum" ifadesine ziyaretçilerin \%46,66's1 "orta düzeyde" ve \%33,33'ü "tam olarak" katılırken; "Yörük köyünde, diğer ziyaret ettiğim yerlerden daha çok keyif aldım" ifadesine ziyaretçilerin \%66,66’s1 “orta düzeyde” katılmıştır. "Bölgeye karşı güçlü bir aidiyet duygusu hissediyorum" ifadesine ise \%63,33'lük oranda "orta düzeyde" katılım sağlanmıştır. Bu cevabı veren katılımcıların \%57,89’u “orta düzeyde”, \%36,84'ü ise “tam olarak” bölgede aldıkları 
hizmetten memnun olduklarını belirtmiştir (Tablo 5). Kadın ve erkekler karşılaştırıldığında, erkeklerin kadın katılımcılara oranla bölgeye karşı daha güçlü bir bağlılık hissettiği görülmektedir (Tablo 4). Bu veriler üzerinden süreli kullanıcıların geçirdikleri zaman dilimi içerisinde bölgeye karşı aidiyet duygularının oluştuğunu söylemek mümkündür. Tüm katılımcıların memnuniyet durumuna bakıldığında ise \%63,33'lük oranın "orta düzeyde" cevabını vermiş olması dikkat çekicidir. Konuyla ilgili yapılan görüşmelerde ürünlerin fiyatlarını uygun bulmayan katılımcıların, yerel halkın bölgeyi ziyaretlerin tek seferlik olacağı kanısıyla hareket ettiğini düşündükleri bilgisine ulaşılmıştır.

Yapılan çalışmalarda deneyimlerin hafiza oluşumuna pozitif bir katkısının olduğu kanıtlanmıştır. Mekanda gerçekleşen deneyimler sırasında oluşan olumlu duygular turistlerin zihinlerinde anıların yaratılmasına katkıda bulunmaktadır. Bu duygular sonucunda, kendini yerle özdeşleştiren ve ona bir şekilde bağlı hisseden turist, orayı tavsiye etme ve oraya geri dönme eğilimindedir (Loureiro, 2014; Vada ve ark., 2019). Bu amaçla turistlere yöneltilen "Burası ile ilgili çok güzel anılarım var" ifadesine \%43,33 oranında "orta düzeyde ve \%20 oranında "tam olarak" katılımın gerçekleşmiş olması, turistlerin bölgeyi yeniden ziyaret etme eğilimlerinin bulunduğu yönünde yorumlanabilir (Tablo 5).

Tablo 4. Kadın ve erkek ziyaretçilerin "Bölgeye karşı güçlü bir aidiyet duygusu hissediyorum" ifadesine katılma oranları.

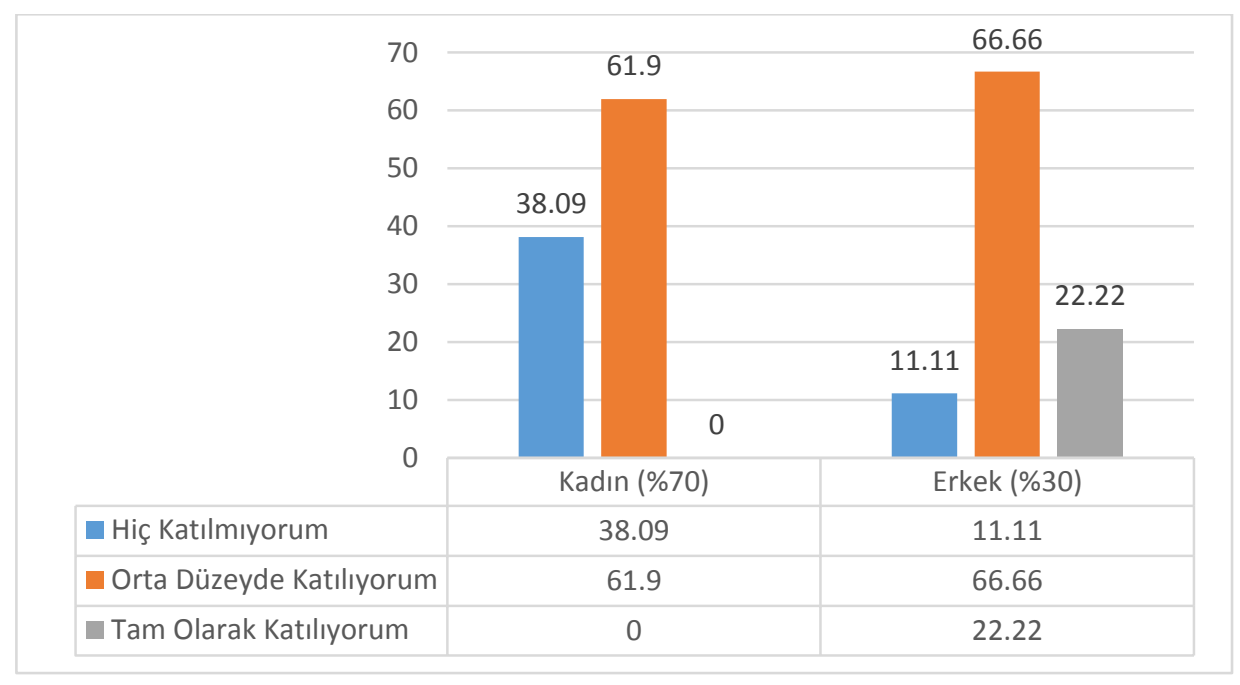


Tablo 5. Mekânsal aidiyet ile ilgili sorulara verilen cevaplar.

\begin{tabular}{l|lcc}
\hline & & $\mathrm{f}$ & $\%$ \\
\hline Bölgede bulunan olanaklardan memnun kaldım. & Hiç & 2 & $\% 6,66$ \\
& Orta & 19 & $\% 63,33$ \\
& Tam & 9 & $\% 30$ \\
\hline \multirow{2}{*}{$\begin{array}{l}\text { Yörük köyünde diğer ziyaret ettiğim yerlerden } \\
\text { daha çok keyif aldım. }\end{array}$} & Hiç & 7 & $\% 23,33$ \\
& Orta & 20 & $\% 66,66$ \\
Bölge ile aramda bir bağ oluştuğunu & Tam & 13 & $\% 10$ \\
hissediyorum. & Hiç & 6 & $\% 20$ \\
\hline \multirow{2}{*}{ Burası ile ilgili çok güzel anılarım var. } & Orta & 14 & $\% 46,66$ \\
& Tam & 10 & $\% 33,33$ \\
\hline
\end{tabular}

\section{Sonuçlar ve Öneriler}

Çalışmada, mekânsal aidiyetin kültür turizmi ile ilişkisi incelenmiştir. Bölgenin kültür turizminden beklenen faydayı sağlayabilmesi için öncelikle ziyaretçilerin bölgede geçirdikleri sürenin artırılması önem arz etmektedir. Ancak bölgede yapılan görüşmelerde, konaklama hizmeti veren yapı sayısındaki azalmanın, ziyaretçilerin köyde bulunma süresinin artırılmasının önündeki en önemli engel olduğu anlaşılmıştır. Bunun yanında köyün dışa göç verme problemi bulunmaktadır ve kullanılmayan konaklarda kalıcı hasarlar oluşmaya başlamıştır. Türker ve arkadaşları (2011) çalışmalarında köy halkının turizmin daha etkin kullanımı ile göç problemin aşılacağını düşündüklerini belirtir. Çalışma sonucunda elde edilen veriler de ziyaretçilerin köye karşı aidiyet duygusu geliştirdiklerini ortaya koymaktadır. Bu ortam, turizmi daha etkin kullanarak göçün önüne geçilmesine katkı sağlamak ve korumayı fiziki çerçevenin yanında, değişen aidiyet ve kimlik yapılarının da dahil olduğu bir modelde uygulamak için köyde gerekli potansiyelin bulunduğunu göstermektedir.

Yere bağlılık, kişinin o mekanda duygusal bağını oluşturan veya geliştiren anlamlarla dolu olduğunda ortaya çıkar. Yere bağlılık kişinin hayatını başka yönlerden de etkilemeye başladığında, bireylerin genel olarak çevreye de daha duyarlı bir davranış şekli gösterme olasılığı da artar (Vaske ve Kobrin, 2001). Urry, eğitim düzeyi yüksek ve profesyonel/yönetimsel mesleklere sahip ileri yaştaki insanların oranındaki artışın, çevreye yönelik kaygının ve belirli türden turizmin artışına yol açtığını belirtir. Özellikle bu etmenler hem ziyaret etme hem de koruma açılarından kırsal kesimin çekiciliğini yükseltmektedir (Urry, 2018). Yörük köyü ziyaretçilerinin yaş dağılımlarına 
bakıldığında, bu konuda gelişmeye hazır bir ortamın oluşturulabileceği düşünülmektedir. Kültürel miras alanlarında turizmin, artan koruma ve çevre bilincinin de etkisiyle ilgi çekici hale gelmesi, iyi planlama ile yürütülmesi bölgenin kalkınmasının yolunu açarken, kültürel ve doğal değerlerin sürdürülebilirliğine de katkı sağlayacaktır.

Aidiyet duygusunun oluşumunda, sosyal alanda gerçekleşen etkileşimler çok sayıda çalışmaya konu olmuş ve fiziksel aidiyete kıyasla daha büyük bir öneme sahip olduğu anlaşılmıştır (Hidalgo ve Hernandez, 2001). Aynı zamanda mekanda gerçekleşen deneyimler sonucunda ortaya çıkan olumlu duyguların ziyaretçilerin anılarına etki ederek mekana bağlılığa katkı sağladığı da bilinmektedir (Loureiro, 2014; Vada ve ark., 2019). Bu bağlamda konaklama ile ilgili problemlerin çözümüyle birlikte süreli kullanıcıların bölgede kaliteli vakit geçirebilecekleri aktiveler üzerine durulması gerekmektedir. Köyün yerel değerlerinin tanıtımı amacıyla ziyaretçiler, bölgenin geleneksel yaşamını deneyimleyerek köy halkı ile daha çok etkileşime girebilir ve sosyal bağların oluşması sağlanabilir. Böylece köyün yerel değerlerinin tanıtımı ve gelecek nesillere aktarımı sağlanabilir.

\section{Teşekkür}

Bu çalışmanın özet bildirimi “18-21 Kasım 2020’de Karabük Üniversitesi, Mimarlık Fakültesi tarafından Safranbolu'da Uluslararası Mimarlık Araştırmaları Sempozyumu (ReseArch'20)" kongresinde sözlü sunum olarak sunulmuş olup, kongre üyelerine teşekkür ederiz.

\section{Kaynaklar}

Altınörs Çırak, A. A. (2019). Tarihi Dokularda Değişen Kimlik ve Aidiyet. Mekânlar/Zamanlar/İnsanlar: Kimlik, Aidiyet ve Mimarlik Tarihi, 151.

Bricker, K. S., and Kerstetter, D. L., (2000). Level of specialization and place attachment: An exploratory study of whitewater recreationists. Leisure sciences, 22(4), 233-257.

Ceylan, S., ve Somuncu, M. (2016). Kültür Turizmi Alanlarında Turizmin Çeşitlendirilmesine Eleştirel Bir Bakış: Safranbolu UNESCO Dünya Miras Alanı. Uluslararası Türk Dünyası Turizm Araştırmaları Dergisi, 1(1), 53-64.

Geçkili, P., (2018). Mekânsal Aidiyet ve Yabancılaşma Bă̆lamında Zeyrek Konut Çevresinin İrdelenmesi. Yüksel Lisans Tezi. İstanbul Teknik Üniversitesi, Fen Bilimleri Enstitüsü, İstanbul.

George, B. P., and George, B. P. (2004). Past visits and the intention to revisit a destination: Place attachment as the mediator and novelty seeking as the moderator. Journal of Tourism Studies, 15(2), 51.

Göçer, A., (2018). Yerleşik Yaşama Geçmiş Yörüklerde Konar-Göçer Yaşamın İzleri Üzerine Bir Kültür Analizi: Yörük Köyü Örneği. Karabük Üniversitesi Sosyal Bilimler Enstitüsü Dergisi, 8(2), 227-241.

Hidalgo, M. C., and Hernandez, B., (2001). Place attachment: Conceptual and empirical questions. Journal of environmental psychology, 21(3), 273-281. 
Kyle, G., Graefe, A. and Manning, R., (2005). Testing the Dimensionality of Place Attachment in Recreational Settings. Environment \& Behavior, 37 (2), 153-177.

Loureiro, S. M. C., (2014). The role of the rural tourism experience economy in place attachment and behavioral intentions. International Journal of Hospitality Management, 40, 1-9.

Low, S., and Altman, I., (1992). Place attachment: A conceptual Inquiry. In I. Althman, \& S. Low (Eds.), Place attachment. New York: Plenum.

Meydan Uygur, S. ve Baykan, E., (2007). Kültür turizmi ve turizmin kültürel varlıklar üzerindeki etkileri. Gazi Üniversitesi Ticaret ve Turizm Eğitim Fakültesi Dergisi, (2), 30-49.

Moore, R. L., ve Scott, D., (2003). Place attachment and context: Comparing a park and a trail within. Forest science, 49(6), 877-884.

Öztürk, S. M., ve Halaç, H. H., (2020, Mart). Tarihi Çevrede Mekânsal Aidiyet: Yörük Köyü Örneği. Ankara II. Uluslararası Bilimsel Araştırmalar Kongresi (s.100-108). Ankara, Türkiye.

Şentürk, A., ve Gülersoy, N. Z., (2019). Aidiyet, Kent Kimliği ve Kentsel Koruma Etkileşimi Bağlamında Kullanıc Sürekliliğinin İrdelenmesi: Kadıköy Moda Örneği. Megaron, 14(1).

Türker, N., Çetinkaya, A., Barutçu, H., ve Emir, G., (2011). Zonguldak, Karabük ve Bartın Illeri Turizm Sektör Analizi. İstanbul: Turmatsan Matbaacılık.

Urry, J., (2018). Mekânları Tüketmek, Çev. Rahmi G. Öğdül, İstanbul: Ayrıntı Yayınları.

Vada, S., Prentice, C., and Hsiao, A., (2019). The influence of tourism experience and well-being on place attachment. Journal of Retailing and Consumer Services, 47, 322-330.

Vaske, J. J., and Kobrin, K. C., (2001). Place attachment and environmentally responsible behavior. The Journal of Environmental Education, 32(4), 16-21.

Yuksel, A., Yuksel, F., ve Bilim, Y., (2010). Destination attachment: Effects on customer satisfaction and cognitive, affective and conative loyalty. Tourism management, 31(2), 274-284.

Warzecha, C. A., and Lime, D. W., (2001). Place Attachment in Canyonlands National Park: Visitors' Assessment of Setting Attributes on the Colorado and Green Rivers. Journal of Park \& Recreation Administration, 19(1).

Williams, D. R., and Roggenbuck, J. W., (1989, October). Measuring place attachment: Some preliminary results. In Abstracts: 1989 leisure research symposium (Vol. 32).

Williams, D.R., and Vaske, J.J. (2003). The measurement of Attachment validity an generalizability of psychometric approach. Forest Science, 49, 830-840. 